\title{
The 'Polluter Pays Principle': environmental liabilities and scientific evidence under the Italian law system
}

\section{III principio "Chi inquina, paga": responsabilità ambientali e prova scientifica nell'ordinamento giuridico italiano}

\author{
Dario Covucci
}

\begin{abstract}
Riassunto: Il principio "Chi inquina, paga" è una pietra miliare nel diritto dell'ambiente. L'ordinamento giuridico italiano, come altri europei, mostra che tale principio, benché facile da comprendere, è difficile da attuare. La giurisprudenza e la prassi confermano che, per applicare questo principio, è necessario un approccio multidisciplinare che combini competenze legali ed expertise tecnica, specialmente quando la contaminazione risale a un lontano passato.
\end{abstract}

\begin{abstract}
The "Polluter Pays" Principle is a cornerstone in environmental law. The Italian law system, like other European ones, show that this principle, although being easy to understand, is hard to be implemented. Case law and experience confirm that a multidisciplinary approach, combining legal competences and technical expertise, is required to make this principle effective, especially when contamination dates to a distant past.
\end{abstract}

Keywords: contamination, legislation, protection hydrochemistry, isotopes.

Parole chiave: contaminazione, legislazione, protezione, idrogeochimica, isotopi.

Avv. Dario COVUCCI 毒"

Partner, LCA Studio Legale

Via della Moscova 18, 20121, Milan, Italy

Ricevuto/Received: 18 October 2019-Accettato/Accepted: 19 December 2019 Pubblicato online/Published online: 20 December 2019

This is an open access article under the CC BY-NC-ND license: http://creativecommons.org/licenses/by-nc-nd/4.0/

(C) Associazione Acque Sotterranee 2019

\section{The "Polluter Pays" Principle: from a general rule to the specific European and Italian legislation}

Under the "Polluter Pays" Principle the polluter - i.e., the party responsible for contamination - is under the legal obligation to remedy environment and pay damages suffered by environmental resources.

Although it seems to reflect common sense, this general principle is a quite recent achievement in the context of environmental law.

At a European level the 'Polluter Pays' Principle was first set out in 1987 under Article 130R of the Sigle European Act (then Article 174 of the European Communities Treaty, now Article 191 of the Treaty on the Functioning of the European Union). It was however Directive 2004/35/CE that established a general framework for environmental liability throughout the EU Member States.

The Italian legal system waited a long time before an overall environmental regulation was enacted.

Indeed, only in the last ' 80 the Italian Constitutional Court and Court of Cassation started construing 'environment' as a 'primary value' protected under the Italian Constitution (which, under Article 117 (2001), embodied 'environmental protection' as a matter of exclusive competence for the Italian legislator) $[P$. Maddalena, La giurisprudenza della Corte Costituzionale in materia di tutela e fruizione dell'ambiente e le novità sul concetto di «materia», sul concorso di competenze sullo stesso oggetto e sul concorso di materie, in Riv. giur. amb., 2010, 685]

Since the very beginning some legal provisions, disseminated in codes and statutes, set out prohibitions, duties, or administrative and criminal sanctions. Reference can be made to: the 'Consolidated Health Laws'; Article 844 of the Italian Civil Code on undue emissions into third party's property; the Italian Criminal Code, including Articles 659 and 674 on dangerous discharging, Articles 434 and 449 on 'environmental disaster', and Article 439 on water poisoning.

Law No. 319 of 10 May 1976 (s.c. "Merli Law") laid down a complete set of rules governing industrial discharges, granted inspection and control powers to public authorities, and required discharges to be restricted within certain limits established in official tables.

Presidential Decree No. 915 of 10 September 1982 and its implementing deed (Interministerial Committee Resolution of 27 July 1984) provided specific rules on waste treatment, 
disposal, storage and landfills. At a wider level, under Article 32 it also required to adopt any measure to prevent worsening of the pre-existing environmental situation.

Finally, the Legislative Decree No. 22 of 5 February 1997 (s.c. "Ronchi Decree") and its implementing regulation (Ministerial Decree No. 471 of 25 October 1999) introduced, for the first time, a comprehensive regulation of the remediation procedure, obligations and steps [Acceptable legal thresholds for a series of parameters were adopted so that a site could be defined 'polluted' whenever the concentrations of certain substances found in soil, subsoil or groundwater resulted in exceeding such limits.].

\section{The remediation procedure under the Italian Environmental Code}

The "Ronchi Decree" has been repealed by Legislative Decree No. 152 of 3 April 2006 (s.c. "Environmental Code" or "EC"). The 'Polluter Pays' Principle is implemented, essentially, by Part IV (remediation procedure) and Part VI (environmental damage compensation) of the Environmental Code. For the purposes of this essay let us consider Part IV only [As to environmental damage compensation, let me refer to Covucci D., Il nuovo statuto del risarcimento del danno ambientale dopo la Legge Europea 2013, in Danno resp., 2016, 6, 6571.

Under the EC contamination can be potential or actual depending on which legal thresholds are exceeded:

a. a site is "potentially polluted" when the concentration values of one or more contaminants are higher than legal 'contamination levels' (Concentrazioni di Soglia di Contaminazione or CSC). The exceedance of these precautionary limits triggers a legal obligation to start remediation procedure, notify public authorities and characterise the site;

b. a site is (actually) "polluted" only when the 'risk levels' (Concentrazioni Soglia di Rischio or CSR) are found to exceed. The 'risk levels' can be defined only upon a sitespecific risk analysis collecting data on risks for human health and environment under the detailed criteria set out by Annex I to Part IV.

Exceedance of the 'risk levels' requires to start up cleanup (bonifica) and/or safety measures (messa in sicurezza). Remediation actions can be selected and designed according to a variety of criteria, including the site characteristics and its current (or future) intended use, the magnitude of contamination, efficiency criteria, economic sustainability, and risks for spreading contaminants.

Furthermore, clean-up actions can be replaced by: (i) 'operating safety measures', when production processes are still operated - and the site cannot be cleaned-up until its decommissioning -, as long as adequate health and environmental safety is guaranteed and the contamination spread is contained; or (ii) 'permanent safety measures' if clean-up is too much expensive and/or technically unfeasible.

Under the EC the 'polluter' only is under legal obligation to perform remediation activities in coordination with public authorities (Article 242). If polluter fails to do so, the private party that owns a contaminated site - provided that it has not contributed to pollution - has the right, not the duty, to notify public authorities of the potential contamination and start a remediation procedure (Article 245).

Under no circumstance can a not-liable owner be ordered to remedy environment at its own costs [However, pursuant to Articles 242 and 245 of the EC, a site owner is obliged to notify the authorities of any 'potential contamination' it has discovered and promptly take 'preventive measures' (misure di prevenzione) to prevent contamination from spreading or worsening the status of other environmental matrices. A question often arises as to whether some measures - like bydraulic barrier or pumpEtreat systems - are merely 'preventive' or must qualify as 'safety measures' (being it understood that the polluter only is obliged to take the last ones). Legal and technical competences may be crucial to help private owners to select appropriate and less burdensome measures, especially when discussing them with public authorities.]

However, if no polluter is identified - or it is found to be insolvent or no longer existing -, public authorities are entitled to perform remediation ex officio and to seek costs reimbursement to the private party.

Indeed, whenever a remediation plan is approved, a property burden (onere reale) is registered over the site. In other terms, public authorities can enforce their right to cost reimbursement against the real estate property owned by the private party. In line of principle, remediation expenses may be (much) higher than the value of the contaminated area; therefore, enforcement of the property burden could de facto result in expropriating such area.

The not-liable private owner has two options to avoid this unlucky scenario: (1) waiting public authorities to identify a polluter and order it to remedy the contamination; or (2) remediating the polluted site on a voluntary basis.

It is therefore clear that search for a polluter plays a key-role in implementing the "Polluter Pays" Principle. Neither public authorities, nor the not-liable owner, would be willing to start remediation procedures and make huge investments in environmental protection if it was very hard, if not impossible, to recover costs, at least partially, from the entity responsible for contamination.

Additionally, production sites or building areas being contaminated are in principle less attractive and sold at a lower price. No chance of recovery for remediation costs may further decrease the assets value or, even worse, discourage potential buyers.

Under this perspective the "Polluter Pays" Principle results in the polluter being legally bound to two alternative obligations, i.e. (1) site remediation or (2) payment of remediation costs borne by not-liable parties.

In implementing this principle, it is also of the utmost importance that geological, hydrogeological and scientific experts help to find evidence and develop techniques also known as 'Environmental Forensics'. 


\section{Looking for the 'polluter': legal principles and environmental forensics}

As a rule, public authorities are obliged to look for and identify the entity that polluted a site or its successor(s). Article 244 of the EC entrusts the Province (i.e., a territorial authority) - now sometimes replaced by the Regional Environmental Agency (ARPA) - to start a specific administrative procedure to find out the responsible for contamination.

However, it may happen that public authorities neglect this task or delay the procedure for a long time. Thus, the private owner that wants to clean-up its own site and expects to recover a part or all of the costs borne, can do nothing else but to urge the authority to proceed [See Lombardy Regional Administrative Court, Milan, Division IV, 15 April 2015, No. 940, which clarified that, although a private owner has voluntarily commenced a remediation procedure, or has even remediated a contaminated site, the public authorities are still legally bound to identify the polluter, being it a specific legal obligation to make the "Polluter Pays" Principle effective, so as to protect both public interests and the economic interests of the not-liable owner.], or disregard the authorities' inertia and take charge of identifying the polluter [Article 253 of the EC has introduced a special subrogation action (azione di rivalsa) under which the not-liable owner can recover the costs paid for site remediation provided that evidence on the polluter's identity and liability is available.].

The Council of State - i.e. the Italian highest administrative Court - has endorsed the principles held by the EU Court of Justice and aimed to polluter identification. These principles, which are consistently applied by a well-established Italian case law, can be summarised as follows [See Council of State, $V$ Division, 26 January 2012, No. 333; EU Court of Justice, Grand Chamber, 9 March 2010, No. 378/08. Plausible clues and indirect evidence to identify a polluter include, for instance, the proximity of the operator's plant to the detected pollution, and the correspondence between pollutants and substances/processes used over the time by an operator to run its business.]:

a. an operator must be "more likely than not" to have contaminated a site;

b. the causal link between the contamination detected and the operator's activities (or omissions) can be proved by direct, indirect or constructive evidence;

c. each of the entities that operated a site (in the same or different periods of time) can be held liable only proportionally to the extent that it has contributed to pollute the site [The same principle of 'proportional' or 'several' liability (responsabilità parziaria) is provided by Article 311, Part VI of the EC, with reference to compensation for 'environmental damage'. It must be noted, however, that the Italian Supreme Court stated that 'proportional' liability does not apply when actions (or omissions) are not independent of each other and contribute, with no distinction, to cause the same environmental damage; as a result, all the site operators can be beld jointly and severally liable for contamination. See Court of Cassation, III Civil Division, 13 August 2015, No. 16806 and 16807, in Danno e resp., 2016, p. 638.].
Although legal principles seem to be clear, uncertainties and difficulties may arise in the real world. Different scenarios may take place, including, with no limitation, the following:

- the site was (or is being) managed (i) by two or more operators, (ii) simultaneously and/or over different periods of time;

- different operators of the same site have used identical or analogous substances and/or manufactured similar products;

- the site is nearby other production (and potentially polluting) areas;

- the overall area including the contaminated site is affected by diffuse pollution (inquinamento diffuso) [Under Article 240, letter $r$ ) of the EC 'diffuse pollution' is defined as "the contamination or chemical, physical or biological alterations of the environmental matrices caused by diffuse sources not traceable to a single origin".];

- contaminants are subject to degradation inside the environmental matrices; and/or

- contamination is 'historical' and evidence is missing or traces back to an old time (see infra).

In these situations, environmental forensics and scientific expertise can turn out to be extremely helpful.

Indeed, to apply the legal principles aimed at identifying a polluter also entails to: (a) reconstruct historical production process and past environmental status; (b) locate present and past primary/secondary sources and keep them separate by operator; (c) 'date' the contamination and link it to one or more operators.

With a focus on underground contamination, traditional instruments (such as characterization of the hydrogeological structure; hydrochemical analyses; mathematical modelling) are now supported by innovative techniques.

For example, chemical fingerprinting allows to match polluting substances with production processes and thus their respective contributors due to prevailing contaminants.

Isotopic fingerprinting can also match an isotopic signature (used as a fingerprint) with a specific source of contamination. This last method, especially, allows to trace distinct sources of contamination, although identical or (very) similar industrial substances were used or produced, based on the quantity of isotopes found in the contaminants at a molecular level. Furthermore, it may help to assess the age of 'historical' contamination, connecting isotopic signatures with production cycles and/or the long-lasting presence of (degradable) contaminants in the environment.

\section{The 'historical' contamination: who pollutes, pays?}

One of the main objections legal counsel were used to raise - and still raise - in court, when defending polluters, is that the new environmental regulation would not apply to a 'historical' contamination. Indeed, both the "Ronchi Decree" and the EC were not in force when contamination started and cannot be applied retroactively, since this way certainty of law would be seriously compromised. 
This topic is critical: if the objection was grounded, the procedures, obligations and contamination/risk limits set out by the new regulations would not apply, thus polluters would have chances to escape liability.

However, today the Italian administrative courts unanimously hold that both the 'Ronchi Decree' and the EC apply to any 'historical' contamination that was still in existence when these laws came into effect, disregarding when the triggering events took place and irrespective of whether the contamination breached any laws in force at the time it occurred.

This legal principle rests on the rationale that pollution gives rise to a permanent situation and continues so long as it is not remedied (i.e., until contaminants are removed and environmental parameters are brought back within the maximum authorised levels).

Also, there is a legal ground. Unlike the 'Ronchi Decree', the EC expressly stipulates that the remediation procedure applies to "historical contaminations that can still entail the risk of worsening the status of contamination" (Article 242, Paragraph 1) and to "events occurred before the moment when Part IV of the EC entered in force but show their impact after that moment" (Article 242, Paragraph 11).

Nonetheless, the course of time makes it harder, or even impossible, to identify an operator (and potentially liable) due to legal reasons and factual factors.

A company that ran a site in the past may have dissolved or got bankrupt, as a result of which nobody can be found liable for pollution. On the contrary, if the 'historical' polluter is merged with another company, the acquiring entity is liable as 'polluter' by way of universal succession. Similarly, if a company is demerged, the entity that continues to exist is liable for any past contamination; and, additionally, the newco resulting from demerger is jointly liable for remediation costs.

The 'polluter' may also sell the site or real estate property it contaminated. It may happen that under the sale purchase agreement the obligations to remedy contaminated areas (and pay related costs) are waived or shifted onto the buyer. These contractual mechanisms are however at odds with the 'Polluter Pays' Principle, as private agreements cannot deviate from the mandatory and unnegotiable rule under which 'who pollutes, pays'. Otherwise, the entire system of environmental risk allocation would be bypassed; and, consequently, the public interest of (ultimately) having a polluter liable for remediation costs would be frustrated [See, inter alia, Council of State, V Division, 23 September 2015, No. 4466; Council of State, VI Division, 10 September 2015, No. 4225.]

From another viewpoint, poor data may be available, which makes it difficult to ascertain what production, substances, waste are associated with site operators. It may be even harder to define the 'baseline', i.e. the environmental situation before that a contamination occurred or, better, each operator started pollution. As seen above, environmental forensics provide both traditional and innovative techniques of undoubted avail. However, to retrieve old analyses, investigation reports, or other kind of evidence dating back to the past, remains advisable as a preliminary step to ease the overall polluter identification process.

\section{Conclusions}

As shown, despite the undeniable progress in the Italian environmental regulation, the 'Polluter Pays' Principle still involves complex issues. A multidisciplinary approach, combining legal with technical expertise, proves to be the gold standard for identifying polluters and is crucial to manage environmental liabilities in the balance of public and private interests.

\section{REFERENCES}

Maddalena P., La giurisprudenza della Corte Costituzionale in materia di tutela e fruizione dell'ambiente e le novità sul concetto di «materia», sul concorso di competenze sullo stesso oggetto e sul concorso di materie, in Riv. giur. amb., 2010, 685.

Covucci D., Il nuovo statuto del risarcimento del danno ambientale dopo la Legge Europea 2013, in Danno resp., 2016, 6, 657

Micciché C., Lambiente come bene a utilità collettiva e la gestione delle lesioni ambientali, in Il diritto dell'economia, vol. 31, no. 95, 2018, $1-41$. 